\title{
FOOD SERVICE FOR CONVICTS IN CORRECTIONAL INSTITUTIONS ACCORDING TO LAWS AND REGULATIONS AND ISLAMIC SHARIA
}

\author{
Ahyar Ari Gayo \\ Researcher of Badan Penelitian dan Pengembangan Hukum dan Hak Asasi Manusia, \\ Kementerian Hukum dan Hak Asasi Manusia Republik Indonesia, Jakarta. \\ Corresponding author. Email: ahvararigavo@gmail.com \\ Received on: 05-10-2021; Revised on: 08-11-2021; Approved to be published on: 10-11-2021; \\ DOI:http://dx.doi.org/10.30641/dejure.2021.V21.435-446
}

\begin{abstract}
The rights of convicts as Indonesian citizens who lost their independence due to criminal acts must be carried out in accordance with human rights. One of them is the right to obtain adequate food and beverage services that meet nutritional and health standards in accordance with the provisions of laws and regulations. In addition, Islamic sharia (law) also regulates the rights of convicts to get good and halal food and drink. This requirement is an order from the Al-Quran and Hadith. The problem of this research is how to organize food according to the provisions of laws and regulations and the provisions of Islamic law. This research used sociological research method. According to the type and nature of the research, the data sources used are secondary data consisting of primary legal materials. The secondary legal materials in this research consist of books, scientific journals, papers and scientific articles that can provide explanations of the primary legal materials. The results of the research found that in practice it was still found in Correctional Institutions that the rights of convicts had not been given in accordance with their rights as citizens. This is caused by several factors, including the lack of understanding of the regulations regarding the rights of convicts contained in the Law and sharia law by correctional Institution officers or even by the convicts themselves. Correctional officers need to be given dissemination regarding their obligation to provide food for convicts in accordance with laws and regulations.
\end{abstract}

Keywords: food; convicts; islamic sharia

\section{INTRODUCTION}

The 1945 Constitution of the Republic of Indonesia, paragraph 4 , states that the Government of the Republic of Indonesia shall protect the entire Indonesian nation and the entire homeland of Indonesia and to promote public welfare, educate the nation's life, and participate in carrying out world order based on independence, eternal peace and social justice. Therefore, there is no dichotomy of the state's responsibility towards the general public with the people who are in Correctional Institutions/Juvenile Development Institutions/ Detention Centers/Detention Center Branches, so that convicts also have the right to obtain facilities related to the necessities of life such as clothing, food, and other facilities.

In connection with the above, Article 14 paragraph 1 (d) of Law Number 12 Year 1995 concerning Corrections also mandates that convicts have the right to receive proper health services and food. As an implementation of these provisions, a Government Regulation has been issued concerning the Requirements and Procedures for the Implementation of the Rights of Correctional Inmates (WBP) which states that every convict and correctional student has the right to get food and drinks that are in accordance with calories and meet health requirements. In addition, the government issued Government Regulation No. 58 Year 1999 concerning Requirements and Procedures for the Implementation of the Authority, Duties and Responsibilities of Care for Convicts, especially article 28 which reads 1 every convict has the right to get food in accordance with the applicable laws and regulations.

Paying attention to some of these provisions, the Minister of Law and Human Rights issued a Ministerial Regulation Number M.HH-01. PK.07.02 Year 2009 concerning Guidelines for the Provision of Food for Correctional Inmates in Correctional Institutions and State Detention Centers (State Gazette of the Republic of 2009 Indonesia Year Number 406, Supplement to State Gazette of the Republic of Indonesia Number 406). Furthermore, on December 29, 2018, the Minister of Law and Human Rights reestablished the Regulation of the Minister of Law and Human Rights Number 40 Year 2018 
concerning Guidelines for the Provision of Food for Detainees, Children and Convicts, namely amending the Ministerial Regulation Number M.HH-01.PK.07.02 Year 2009 concerning Guidelines for the Provision of Food for Convicts in Correctional Institutions and State Detention Centers.

Regulation of the Minister of Law and Human Rights Number 40 Year 2018 concerning Guidelines for the Provision of Food for Detainees, Children and Convicts regulates several matters related to the Mechanism of Food Provision in Correctional Institutions/Juvenile Development Institutions/Temporary Child Placement Institutions/State Detention Centers/Branches of State Detention Centers; Standardization of Nutritional Adequacy; Human Resources and Equipment Required for Food Service. ${ }^{1}$

Based on the results of research conducted by the Research and Development of the Corruption Eradication Commission and Monitoring Evaluation conducted by the Directorate General of Corrections, it was found that the implementation of the Regulation of the Minister of Law and Human Rights No. 40 Year 2017 was not optimal because many things, including the lack of adequate human resources and infrastructure, so that the objectives desired by this Regulation of the Minister of Law and Human Rights could not be achieved. For example, one of them is the nutritional standard determined by the Minister of Health regarding the standard of nutritional adequacy for Indonesian people.

Meanwhile, Islamic law pays attention so much to the patterns and lifestyles of its people. Such as by providing a number of rules and prohibitions regarding food ingredients that will be consumed by humans. Islam regulates well the presentation of food to be given. Information about the pahala (reward) of feeding is scattered in the vast Islamic literature. For example, in al-Jami' al-Shagir, Imam Jalaluddin al-Suyuthi quotes a hadith of the Prophet PBUH about people who will get protection under the Arasy (Throne) of Allah SWT. They are those who feed the hungry. ${ }^{2}$

\footnotetext{
Lihat Balitbangkumham, penelitian Hukum Tentang Evakuasi Permenkum 4o Tahun 2017 tentang Pedoman Penyelenggaraan Makanan Bagi Narapidana

2 M.A. K.H. Dr. Syamsul Yakin, "Pahala Memberi Makan," Republika.co.id, last modified 2020, diakses Juli 5, 2021, https://www.republika.co.id/berita/
}

Not only rewarding, feeding even praised by the Prophet PBUH, "Indeed the best among you is the one who feeds." (Hadith narrated by Thabrani). A man asked the Prophet PBUH, "What is the best deed in Islam?" The Prophet PBUH replied, "You feed other people." (Hadith narrated by Bukhari and Muslim).

From the brief description of the background above, it is necessary to re-examine why the Regulation of the Minister of Law and Human Rights Number 40 Year 2017 has not been optimally implemented and what factors cause it.

\section{RESEARCHMETHOD}

This research used sociological research method. According to the type and nature of the research, the data sources used are secondary data consisting of primary legal materials and secondary legal materials such as books, scientific journals, papers and scientific articles that can provide explanations of primary legal materials.

The analysis of the legal materials was carried out using qualitative analysis method which was used to explain legal events and legal materials or legal products in detail in order to facilitate legal interpretation. ${ }^{3}$

\section{DISCUSSION}

\section{A. Provision of Food for Convicts Based on Regulation of the Minister of Law and Human Rights No. 40 Year 2017}

Correctional Inmates (WBP) in the Laws and Regulations require the right to obtain food that meets eligibility. The right to food is necessary for life because food is one of the main needs in everyday life for humans. Processes in the body need to function in growth and development with food intake, restore damaged body tissues, increase energy in daily activities, and regulate metabolism and balance water, minerals and body fluids. Food intake also plays a role in the defense mechanism in the human body against all kinds of diseases. Fulfillment of food rights is not just

\footnotetext{
qbp2nd374/pahala-memberi-makan.

3 Rahmat Ramadhani, "Eksistensi Hak Komunal Masyarakat Hukum Adat Dalam Pengadaan Tanah Untuk Kepentingan Umum (Indigenous Legal Communal Rights in the Land Acquisition for Public Purposes)," Jurnal Penelitian Hukum DE JURE 19, no. 1 (2019): 97-108.
} 
providing food without paying attention to the quality and quantity of food received. Increased nutrition in food needs to be considered and one shall weight the calorie content and nutritional value of each component of the food to be eaten. The fulfillment of nutritional needs in food needs to be in accordance with health standards and nutritional adequacy. ${ }^{4}$

The provision of food that is not in accordance with the quality and quantity can cause health problems. Malnutrition causes a person to be susceptible to disease, lack of motivation and apathy. This condition is certainly not something that is desired for correctional inmates, because it can increase the burden at correctional institutions/ detention centers and interfere with efforts to realize the welfare of the correctional inmates. Foods that meet nutrition are foods that contain enough carbohydrates, proteins, fats, minerals, vitamins, and in a balanced amount according to the body's needs. The right to food that can be fulfilled by providing food requires commitment and enthusiasm from the correctional institutions/ detention centers and other elements around them. Adequate food is food that meets the needs of the body at a certain age and condition. Foods that are below health standards are foods that do not have good benefits for the body and even damage the body from time to time. Therefore, apart from nutrition, it is also necessary to pay attention to hygiene and sanitation. ${ }^{5}$

Convicts need to be protected from food and drink that do not meet health requirements so as not to endanger their health. Food and drinks for Correctional Inmates need to meet health standards. Therefore, it is necessary to perform proper supervision for the provision of food for Correctional Inmates. Food is a basic human need that is needed at all times and wherever they are. Food requires good and correct management to be beneficial for the body. Without food and drink, humans cannot survive. Good food ingredients are sometimes difficult to find, because the food

\footnotetext{
4 Manan Sailan dan Irfana Lutia Ilyas, "Implementasi Pemenuhan Hak Mendapatkan Makanan Yang Layak Bagi Narapidana Di Lembaga Pemasyarakatan Klas 1 Makassar,"Jurnal Supremasi 13, no. 2 (2018): 95.

5 Wessy Tiana Aliftha Rozakiya, Agus Salim Daulay, “Tinjauan Hukum Terhadap Pemberian Pelayanan Kesehatan Dan Makanan Terhadap Narapidana (Studi Kasus Di Lembaga Pemasyarakatan Tanjung Gusta Medan)," Jucto 1, no. 1 (2019): 23.
}

service network is so long and through such a wide trading network. One effort to get good food is to avoid using food ingredients that come from unclear sources because they cannot be accounted for in terms of quality. For this reason, food ingredients that enter correctional institutions need to be thoroughly checked so that there are no food ingredients that are damaged because their nutritional content has decreased and is not good for the health of correctional inmates. In correctional institutions, auctions are held once a year to determine the contractors who will distribute the food each day.

The definition of food according to WHO (World Health Organization) is all substances needed by the body, except water and drugs and substances used for treatment. Food and drink are the most important basic needs in human life because they are the only source of energy. Therefore, anything that will be served as food or drink needs to meet the main requirements standards, namely the taste of food and food safety in the sense that the food does not contain substances or microorganisms that can interfere with the health of the body of the person who eats it. Food and drink are basic human needs that are needed at all times and need to be handled and managed properly and correctly to benefit the body. Proper and correct management is basically managing food and beverages based on the principles of food hygiene and sanitation. Food and beverage hygiene and sanitation is an effort to control the factors of food, people, places and/ or equipment. ${ }^{6}$

Article 29 paragraph (1) of Government Regulation No. 58/1999 states that officers of Detention Centers/Branches of Detention Centers or Correctional Institutions/Branches of Correctional Institution that manage food are responsible for:

a. Food hygiene and compliance with food health and nutrition requirements;

b. Provision, storage and preparation of food; and

c. Maintenance of food utensils and cooking utensils.

\footnotetext{
6 Manan Sailan dan Irfana Lutia Ilyas, "Implementasi Pemenuhan Hak Mendapatkan Makanan Yang Layak Bagi Narapidana Di Lembaga Pemasyarakatan Klas 1 Makassar.": 94-104
} 
Therefore, basically, both detainees and convicts have the right to get proper food and Detention Center and correctional institution officers are obliged to provide proper food for detainees and convicts.

The food consumed should meet the criteria that the food is fit to eat and does not cause disease, including:

a. Within the desired degree of maturity

b. Free from pollution at every stage of production and subsequent handling.

c. Free from unwanted physical and chemical changes, as a result of the influence of enzymes, microbial activity, rodents, insects, parasites and damage caused by pressure, cooking and drying.

d. Free from microorganisms and parasites that cause foodborne illness. ${ }^{7}$

\section{Food Ingredient Storage}

The purpose of storing food ingredients is so that the food ingredients are not easily damaged and lose their nutritional value. Food ingredient damage can occur due to contamination with bacteria due to nature or human treatment and mechanical damage such as friction, impact pressure, etc. All food ingredients are cleaned before being stored to be free from bacteria. This can be done by washing. After drying, the food ingredients are then wrapped in a clean wrapper and stored in a low temperature room. In storing food ingredients, on thing that needs to be considered is that the food ingredients must be stored in a special place that is clean and meets the requirements.

Items should be arranged properly so that they are easy to pick up, not become nesting places or hiding places for insects and rats, and the food ingredients are not easily decomposed and damaged. For perishable ingredients, it is necessary to provide a cold storage area. Every food ingredient must have a record card so that it can be used for the history of goods in and out with the FIFO (First In First Out) system.

There are four ways of storing food according to its temperature:

Kresnoputranto, Kesehatan Lingkungan (Jakarta: FKM Universitas Indonesia, 1986). Hal. 15 a. Cooling storage, namely storage temperature of $10^{\circ} \mathrm{C}-15^{\circ} \mathrm{C}$ for types of fruit drinks, ice cream and vegetables.

b. Chilling storage, namely storage temperature of $4^{\circ} \mathrm{C}-10^{\circ} \mathrm{C}$ for protein food ingredients that will be reprocessed soon.

c. Freezing storage, namely storage temperature of $0^{\circ} \mathrm{C}-4^{\circ} \mathrm{C}$ for perishable protein ingredients for a period of up to 24 hours.

d. Frozen storage, namely storage temperature of $<0^{\circ} \mathrm{C}$ for perishable protein food ingredients for a period of $>24$ hours.

\section{Food Processing}

In addition to storage, it is also necessary to pay attention to food processing. Food processing is the process of transforming raw ingredients into ready-to-eat food. Good food processing is one that follows the principles of hygiene and sanitation. In this case, the requirements for cook and equipment in the processing need to be considered. The requirements for a cook are:

a. Healthy body condition with a doctor's certificate.

b. Free from infectious diseases (TB, Typhus, cholera, disease carriers).

c. Must have a health check book.

d. Do not smoke while processing food.

e. Do not eat or chew.

f. Do not wear jewelry except for unadorned wedding ring.

g. Do not use equipment and facilities that are not for their purposes.

h. Always wash hands before starting work.

i. Always wear proper work clothes and protective clothing.

j. Always wear clean work clothes and the clothes must not be worn outside of working hours.

Regarding the provision of food for detainees, children, and convicts, the government through the Ministry of Law and Human Rights (Kemenkumham) has regulated the obligations to provide food hygiene and the fulfillment of food health and nutrition requirements as stipulated in the Regulation of the Minister of Law and Human Rights Number 40 Year 2017 concerning Guidelines for the Provision of Food for Detainees, Children, and Convicts. The 
implementation of the Regulation of the Minister of Law and Human Rights Number 40 Year 2017 concerning Guidelines for the Provision of Food for Juvenile Detainees and Convicts in Detention Centers, Juvenile Development Institutions, and Correctional Institutions still faces problems.

Based on information search conducted by the researcher, both through virtual ${ }^{8}$ and direct interviews with respondents ${ }^{9}$ regarding whether or not existing regulations are adequate in order to support the provision of food for detainees, children, and convicts in Detention Centers, Juvenile Development Institutions, and Correctional Institutions, all respondents stated that it was sufficient. However, according to the researcher, there are still some things that do not exist and need to be regulated, such as the provision of food in Correctional Institutions in an emergency situation and it is also necessary to include Mandela Rules in the consideration of the Regulation of the Minister of Law and Human Rights.

Efforts to fulfill the right to food for detainees actually reflect the presence of a complete state perspective that detainees are human beings to whom human rights attached. This perspective is built on the foundation of thinking that human existence does not exist in a vacuum. There is a strong relationship between the fulfillment of one right with other rights as a unit that can build human dignity.

Human detainees are human beings with dignity like humans in general. The detention room in Indonesia, with the nomenclature of Correctional Institution (Lapas), Detention Center (Rutan) and Juvenile Development Institution (LPKA), is an institution established by the state to ensure law enforcement. In these institutions, human detainees are a vulnerable group because they are people deprived of their liberty. Various development programs are carried out to strengthen and improve human identity and of course they are in a massive cycle of vulnerability. This position and condition must not then be

\footnotetext{
8 Tim Peneliti, Penelitian Hukum tentang Evaluasi Permenkum 40 Tahun 2017 tentang Evaluasi Atas Implementasi Permenkumham Nomor 40 Tahun 2017 tentang Pedoman Penyelenggaraan Makanan Bagi Tahanan Anak dan Narapidana di Rutan, LPKA, dan Lembaga Pemasyarakatan, 2021.

9 Ibid.
}

exacerbated by various discriminatory treatments, let alone stimulate violence and corrupt behavior.

The presence of a food management policy for detainees is an urgent matter. Detainees are entitled to the right to proper food in addition to other related rights in order to sustain the existence of the human dignity of the detainees.

This opinion is confirmed by the respondents in this research who said that they are officers who are given the obligation by laws and regulations to provide the best service for and to serve the convicts in the correctional institutions that they foster. As for the food and beverage service mechanism for detainees, children, and convicts at Detention Centers, Juvenile Development Institutions, and Correctional Institutions, they perform it by way of serving food items in accordance with the $S O P^{10}$ for serving food and drink for detainees and correctional students. Food that has been processed and organized by the Kitchen Officer/ worker is served to the detainees by delivering the food to the Detainee's Residential Block after the food is checked by the Security Shift Officers, and the food sample is approved by the head. For correctional students, eating and drinking are done in the dining room which is supervised by security officers.

The respondents' information is in line with Rizkan Zulyadi's statement ${ }^{11}$ that every citizen has the right to get protection from the State and also has the right to develop his own quality, including the right to the opportunity to attend education, and on the other hand is obliged to obey the applicable law and not be a nuisance to the community, even further he/she is demanded to actively participate in community development activities in their environment. Convicts as citizens actually harm the community with their crimes. As a result of their crime, they must accept

1o Republik Indonesia dan Menteri Hukum dan HAM, Lihat, SK Dirjen PAS Nomor: PAS-498. PK.01 .07.02 TAHUN 2015 TENTANG STANDAR PENYELENGGARAAN MAKANAN DI LEMBAGA PEMASYARAKATAN, RUMAH TAHANAN NEGARA DAN CABANG RUMAH TAHANAN NEGARA (Jakarta, 2015).

"Tim Peneliti, Penelitian Hukum tentang Evaluasi Permenkum 40 Tahun 2017 tentang Evaluasi Atas Implementasi Permenkumham Nomor 40 Tahun 2017 tentang Pedoman Penyelenggaraan Makanan Bagi Tahanan Anak dan Narapidana di Rutan, LPKA, dan Lembaga Pemasyarakatan. 162 
the risk of being a convict who is forced to suffer from social isolation. But at the same time, they remain citizens who have the right to protection from their country. On that basis, they must be treated humanely, not outside the boundaries of human rights.

Miriam Budiardjo ${ }^{12}$ states that "Human rights are rights that humans have that have been obtained and brought along with their birth in society life. It is considered that some of these rights are owned without distinction on the basis of nation, race, religion, and sex and are therefore universal. The basis of all human rights is that humans have the opportunity to develop according to their dignity and ideals.

Basically, both detainees and convicts have the right to get proper food and Detention Center and Correctional Institution officers are obliged to provide proper food for detainees and convicts. One of the main tasks of Correctional Institutions, Detention Centers and Detention Center Branches in organizing activities in the health and care sector is to provide food services according to nutritional standards for Correctional Inmates which meet the requirements for adequate nutrition, hygiene and taste as part of efforts to prevent disease and other health problems. This is explained in the Corrections Law, specifically in Article 14 of the Corrections Law, regarding the rights that must be fulfilled, including the right to obtain proper food services. This means that all Correctional Inmates must get nutritious food that is appropriate for health and stamina, of good quality, cooked and served well. This is in line with the Regulation of the Minister of Law and Human Rights Number 40 Year 2017 concerning Guidelines for the Provision of Food for Detainees, Children and Convicts.

Convicts' right to proper food is further regulated in Government Regulation No. 32 Year 1999 concerning Requirements and Procedures for the Implementation of the Rights of Correctional Inmates as last amended by Government Regulation No. 99 Year 2012 concerning the Second Amendment to Government Regulation No. 32 Year 1999 concerning Requirements and Procedures for the Implementation of the Rights

${ }^{12}$ Yuliana Primawardani, "Perawatan Fisik Terkait Penyediaan Makanan Dan Minuman Bagi Narapidana Di Lembaga Pemasyarakatan Ditinjau Dari Pendekatan Hak Asasi Manusia," Jurnal Ilmiah Kebijakan Hukum 11, no. 2 (2017): 165. of Correctional Inmates. In Article 19 paragraph (1) of the Government Regulation, it is stated that every convict and correctional student has the right to get food and drink in accordance with the number of calories that meet health requirements. ${ }^{13}$

Efforts to improve the health and nutritional status of the community in the context of realizing independent Indonesian human resources for healthy living are directed at achieving a condition in which the Indonesian people, including those in correctional institutions (Lapas) and state detention centers (Rutan), are aware, willing and able to identify, prevent and overcome health problems faced, so that they can be free from health problems, both those caused by diseases including health problems due to disasters and the environment and behaviors that do not support healthy living. The nutritional status of correctional inmates is strongly influenced by the quality and amount of nutrients consumed and the presence or absence of disease.

According to Hendra ${ }^{14}$, regarding general health, high nutritional intake causes the increase of degenerative diseases (heart disease, hypertension, kidneys disease, diabetes mellitus, etc.) and if the nutritional intake is low, it will result in an increase in infectious diseases, anemia, decreased immunity, etc.

At the end of this description, it is better if we look at the opinion of Sani Imam Santoso ${ }^{15}$, where he said that law is a very complex and very technical matter, so that we often meet people who are dealing with the law who are impatient and even become very cynical. However, the law inevitably remains one of the most important concerns of civilized human beings everywhere, because the law can provide or offer protection from the

13 Hukum Online, "pengaturan pemberian makanan pada tahanan dan narapidana," hukumonline.com, https://www.hukumonline.com/klinik/detail/uan/ lt543166ffgf328/pengaturan-pemberian-makananpada-tahanan-dan-narapidana.di akses, 25 Agustus 2021

${ }_{14}$ Tim Peneliti, Penelitian Hukum tentang Evaluasi Permenkum 40 Tahun 2017 tentang Evaluasi Atas Implementasi Permenkumham Nomor 40 Tahun 2017 tentang Pedoman Penyelenggaraan Makanan Bagi Tahanan Anak dan Narapidana di Rutan, LPKA, dan Lembaga Pemasyarakatan.159

15 Sani Imam Santoso, PENJARA SWASTA Sebuah Pendekatan Kriminologi dan Teori Keadilan Untuk Kepatutan di Indonesia (Jakarta: Sabero Inti Persada, 2019). hal 51 
powerful, namely government institutions, and it also sometimes moves to protect themselves from their actions from attacks by the weak that actually harm the weak, namely the community, such as abuse of authority of officials.

The above is in line with the results of the author's research in several Correctional Institutions, where the Government in managing Correctional Institutions is indeed very ideal and allows those in Correctional Institutions in Indonesia to be fulfilled all their needs even though with limited quality and adequacy. Even though it is very relative, but at least the Government is trying to humanize human beings who are under the power of law as detainees. The findings include:

1. Almost none of the convicts went hungry. Although the food portions are limited and the taste is sometimes inadequate, the food rations are certain, even the daily menu has been determined. Sometimes the menu contains boiled eggs, tempeh or tofu, beef or chicken, fish, vegetables and extra food in the form of mung bean porridge. It is certain that no one does not eat, then of course there is no hunger.

2. The occupants are healthy and few die in prison. It is rare for correctional inmates to get sick.

3. Bhineka Tunggal Ika. Correctional Institution is a place where all races, ethnicities and religions merge into one. Everyone gets the same treatment.

4. Many also turn out to be good and pious. Convicts are required to always be disciplined in doing many things. Starting from waking up, taking shift, eating and exercising, these make them healthier. In addition, in Correctional Institutions they are required to worship according to their respective religions, this has an impact on them to reflect on what they have done, this has an impact on them being better when they get out of the Correctional Institutions.

5. There are also many works of art in prison. Correctional Institutions also provide guidance in terms of arts and other skills.

\section{B. Feeding Convicts According to Islamic Law}

\section{The Definition of Islamic Law}

Islamic law is a system of rules based on the revelation of Allah SWT and the Sunnah of the Messenger regarding the behavior of the mukallaf (people who can already be burdened with obligations) that are recognized and believed, which are binding on all adherents. ${ }^{16}$ This refers to what the Messenger has done to carry it out totally. Sharia according to the term means the laws ordered by Allah SWT for His people brought by a Prophet, both those related to belief (aqidah) and those related to amaliyah.

Islamic law according to language means the path through which mankind goes to Allah. And it turns out that Islam is not only a religion that teaches about how to worship God only. The existence of rules or systems of provisions of Allah SWT to regulate human relation with Allah and humans with each other. These rules are rooted in all Islamic teachings, especially the Al-Quran and Hadith. Islamic law is sharia which means rules made by Allah for His people brought by a Prophet PBUH, both laws related to belief (aqidah) and laws related to amaliyah (deeds) carried out by all Muslims.

Islam is a religion of mercy to the universe. The sharia stands for the benefit of mankind. All human actions have been regulated in Islamic law. Islam exists not only for mankind, but for all human beings. In Islam, the glory and the rank of human status are not measured by wealth and position, but from the piety and faith of humans. Islamic law reaches all domains of both free people and convicts.

According to Sheikh Abdul Hayy Yusuf in his paper entitled "Ad Dhawabith As-Syar'iyyah fi Muamalat al-Asra", he put forward the principles and ethics that Islam applies to convicts. The basic principle of Islam's attitude towards convicts is good treatment. This is as emphasized by the Prophet Muhammad PBUH after the Battle of Badr. The Prophet advised to treat convicts well. "Do not do evil to them," he said. ${ }^{17}$

16 https://id.wikipedia.org/wiki/Hu kum Islam di Indonesia\#: : :text=Hukum\%2oIslam\%2oatau\%20 syariat $\%$ zoislam,yang\%2omengikat $\% 2$ obagi $\% 20$ semua\%2opemeluknya., diakses 16 AGUSTUS 2021

${ }_{17}$ Syeikh Abdul Hayy Yusuf, "Keluhuran Nilai Islam Memperlakukan Narapidana,” Republika.co.id, 
The nobility of Islamic values in treating convicts is said to have attracted sympathy and brought guidance to the Quraysh infidels. One of them is Tsamamah bin Atsal. Tsamamah bin Atsal was caught in the battle of Badr and then held captive in the Nabawi Mosque. Tsamamah bin Atsal was treated very humanely. Eating and drinking are guaranteed. In fact, Rasulullah PBUH routinely greeted him for three consecutive days. Finally, Tsamamah was released. Tsamamah bin Atsal also converted to Islam.

Tsamamah bin Atsal emphasized that the good treatment for convicts was a noble Islamic guidance. This is in accordance with the call in the Al-Quran. Dignified treatment includes guarantees of proper food, drink, clothing, medicine, and good speech. Fulfillment of consumption for prisoners is a custom that must be met by local authorities. It is said that Rasulullah and his companions always gave the prisoners breakfast and dinner with the same menu, such as bread and dates.

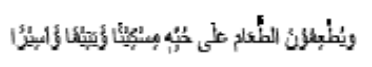

"And they give food in spite of love for it to the needy, the orphan, and the captive." (Quran Surah Al-Insan [76]: 8).

Islam is a teaching that places humans in a very high position, even the Al-Quran guarantees the right of exalting and prioritizing humans, as in the surah Al-Isra' verse 70 below:

و

"Indeed, We have dignified the children of Adam, carried them on land and sea, granted them good and lawful provisions, and privileged them far above many of Our creatures” (Quran Surah Al-Isra: 70) ${ }^{18}$

\section{Criteria for Halal Food According to Islamic Law}

As described above, the provision of food for correctional inmates at Correctional Institutions, Detention Centers and Detention Center Branches is one of the activities to meet the nutritional needs of correctional inmates, so that daily activities both

last modified 2018, https://republika.co.id/berita/ dunia-islam/islamnusantara/18/o2/o5/p3oh5a313keluhuran-nilai-islam-memperlakukannarapidana. Diakses 25 Agustus 2021

18 AL-Qur'an dalam Https://quran.kemenag.go.id/, AlIsra Ayat 70 (Jakarta: Kementerian Agama Republik Indonesia, 2021). physically and spiritually as well as socially can run well. This must be done because the treatment towards correctional inmates must adhere to the basic concepts or basic values contained in the Minimum Standard of Rules which state that every imprisoned person should be provided with food by the head of the agency/institution.

Article 14 of Law No. 12 Year 1995 concerning Corrections, point $\mathrm{d}$, mandates that convicts have the right to obtain health services and proper food. This must be done because the treatment towards convicts must adhere to the basic concepts or basic values contained in the Universal Declaration of Human Rights, which implies that even though they are human beings who are found guilty/misguided and are undergoing development at Correctional Institutions and Detention Centers, they remain members of the community and as human being they have the same rights as other members of the community who are outside Correctional Institutions, Detention Centers and Detention Center branches including the right to get proper food service.

The provisions of the article above are in line with the concept of Islamic sharia where food is one of the important things that is considered by Islam. This is because what is consumed by a person does not only affect the condition of the body and health. Moreover, food or anything that enters the human body determines whether a prayer will be answered or not. People who guard themselves from everything that is haram (forbidden) will be more easily accepted by Allah when he prays.

The following are some of the main criteria for halal food according to Islam, namely:

1. The contained substances are halal

The first thing that becomes the clearest criteria for halal food is the substance it contains or the ingredients. Food must be made from animals and plants that are halal to eat. In general, food items that are categorized as haram are pork, dog meat, fanged animals, and several other animals that are prohibited for consumption.

If a food is made of other than the ingredients that are forbidden, then the food is allowed to be consumed. On the other hand, if the food contains ingredients that are forbidden, even if only in a small amount, the food is classified as haram food and should not be eaten. 


\section{Obtained in a Halal Way}

After meeting the criteria in terms of ingredients, then all existing food can be categorized as halal food and may be consumed by Muslims. However, these foods can become haram foods if the method of obtaining them is not good.

For example, food obtained by stealing, adultery, cheating, the proceeds of usury, corruption, and so on is also considered haram food. This is because the money used to get the food comes from something that is not good. Therefore, the food consumed also becomes haram even though the substances contained are halal substances.

\section{Processed in a Halal Way}

Furthermore, halal food must also be processed in a halal way and not mixed with anything that is haram. For example, by using the same cooking utensils as the cooking utensils used to cook haram food.

Food made in this way can also be categorized as haram food. Apart from the same cooking utensils, a food can also be considered haram if it uses other ingredients that are not allowed during the cooking process.

\section{Served and Stored in a Halal Way}

Lastly, halal food must also be served and stored in a halal manner. Although it seems trivial, the way food is served and stored cannot be ignored. Halal food must not be served with something haram, for example by using cutlery made of gold.

In addition, the process of food storage must also be confirmed that it is halal. Do not mix halal food with non-halal food in one place. This is feared to make food that was previously halal turned into haram.

Those are the criteria for halal food according to Islam. The existence of these criteria is not a form of limitation and difficulty for a servant. On the contrary, Islam is very concerned about everything in the lives of its adherents, including what is consumed by Muslims. ${ }^{19}$

19 SDIT Al Hasanah, "Bagaimana Kriteria Makanan Halal Menurut Islam?," https://sdit.alhasanah.sch. id/, last modified 2020, https://sdit.alhasanah.sch.id/ pengetahuan-umum/bagaimana-kriteria-makananhalal-menurut-islam/. Diakses 25 Agustus 2021
Furthermore, the halal food and drink that are served must also be processed correctly. Animals, such as goats, chickens, cows, if slaughtered in a way that is not in accordance with Islamic law, become haram. As stated in the argument about halal and haram food and drink:

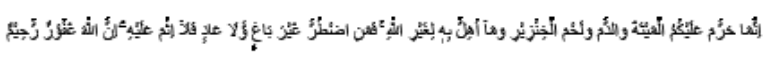

173. He has only forbidden you to eat carrion, blood, swine, and what is slaughtered in the name of any other than Allah. But if someone is compelled by necessity - neither driven by desire nor exceeding immediate need - they will not be sinful. Surely Allah is All-Forgiving, Most Merciful. (Surah Al-Baqarah: 173).

Meanwhile, the criteria for halal food according to Islam that may be consumed include ${ }^{20}$ :

1. $\quad$ Plants, fruits, and seeds.

All types of plant foods, fruits, seeds and their processed products are included in the category of halal food. But what should be a concern is that these foods do not contain substances that can damage or poison the body.

2. Some land animals and water animals.

Category of halal food from land animals that is good for consumption is animals that live around humans and are fed by humans, such as livestock. As for the category of aquatic animals that live in water, it includes animals that live in water which will die if they come out of water, such fish and other marine animals.

A hadith explains about this that "it is halal for you to eat animals obtained from fishing and food (originating) from the sea as delicious food for you, and for those who are on their way".

There are also animals that live on land and water. According to the opinion of the scholars, all animals that live in these two realms are halal except for frogs, crocodiles and turtles, because there is a hadith that forbids them.

\section{Does not contain harmful chemicals.}

Chemical substances such as chemical pesticides, chemical fertilizers, chemical dyes and flavors as well as chemical preservatives, such as formalin, are not allowed because they pose a

${ }^{20}$ HIJUP, "Kriteria Makanan Halal Menurut Islam," https://www.hijup.com/, last modified 2016, https:// www.hijup.com/magazine/kriteria-makanan-halalmenurut-islam/., diakses 25 Agustus 2021 
risk to the performance of organs in the body. The possibility of getting sick increases, even causing death.

4. Does not expire or rot.

Expired food can cause changes in the color, taste and smell of food. Usually this happens in processed foods that are past their expiration date. Likewise, rotting food such as animal carcasses. In Surah Al-Maidah verse 3, it is explained as follows:

"Forbidden to you are carrion, blood, and swine; what is slaughtered in the name of any other than Allah; what is killed by strangling, beating, a fall, or by being gored to death; what is partly eaten by a predator unless you slaughter it." (Surah Al-Maidah: 3)

5. Slaughtered in the name of Allah.

Although livestock are included in the criteria for halal food for consumption, they must still be slaughtered in the name of Allah SWT. If not, it is feared that the slaughtered animal will not be a blessing and will not benefit those who eat it. As mentioned in the surah Al-An'am verse 121 below:

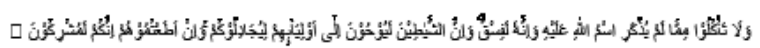

121. Do not eat of what is not slaughtered in Allah's Name. For that would certainly be an act of disobedience. Surely the devils whisper to their human associates to argue with you. If you were to obey them, then you too would be polytheists (Surah Al-An’am: 121).

\section{CONCLUSION}

The issuance of the Regulation of the Minister of Law and Human Rights Number 40 Year 2017 aims that the food provided to convicts can meet the nutritional standards set by the Government. But in reality, this has not been realized due to the limited available budget and the absence of human resources who are nutritionists to monitor the dishes to be served.

According to Islamic law, every food given to Muslims must be halal and good pursuant to the provisions of the Al-Quran and Hadith.

\section{SUGGESTION}

Correctional officers need to be given dissemination regarding their obligation to provide food for convicts in accordance with applicable laws and regulations and based on the provisions stipulated in the Al-Quran and Hadith.

\section{ACKNOWLEDGEMENT}

The author would like to thank the Head of the Research and Development Board for Law and Human Rights who has always encouraged me in writing this scientific paper and I would like to express gratitude to the Editorial Board of the De Jure Legal Research Journal who has always been faithful to help until this paper deserves to be published.

\section{BIBLIOGRAPHY}

Aliftha Rozakiya, Agus Salim Daulay, dan Wessy Tiana. "Tinjauan Hukum Terhadap Pemberian Pelayanan Kesehatan Dan Makanan Terhadap Narapidana (Studi Kasus Di Lembaga Pemasyarakatan Tanjung Gusta Medan).” Jucto 1, no. 1 (2019): 23.

HIJUP. "Kriteria Makanan Halal Menurut Islam.” https://www.hijup.com/. Last modified 2016. https://www.hijup.com/magazine/kriteriamakanan-halal-menurut-islam/.

Https:/quran.kemenag.go.id/, AL-Qur'an dalam. Al-Isra Ayat 70. Jakarta: Kementerian Agama Republik Indonesia, 2021.

Hukum Online. "pengaturan pemberian makanan pada tahanan dan narapidana." hukumonline. com. https://www.hukumonline.com/klinik/ detail/uan/lt543166ff9f328/pengaturanpemberian-makanan-pada-tahanan-dannarapidana.

Indonesia,Republik,danMenteriHukumdanHAM. Lihat, SK Dirjen PAS Nomor: PAS-498.PK.01 .07.02 TAHUN 2015 TENTANG STANDAR PENYELENGGARAAN MAKANAN DI LEMBAGA PEMASYARAKATAN, RUMAH TAHANAN NEGARA DAN CABANG RUMAH TAHANAN NEGARA. Jakarta, 2015. 
K.H. Dr. Syamsul Yakin, M.A. "Pahala Memberi Makan.” Republika.co.id. Last modified 2020. Diakses Juli 5, 2021. https://www. republika.co.id/berita/qbp2nd374/pahalamemberi-makan.

Kresnoputranto. Kesehatan Lingkungan. Jakarta: FKM Universitas Indonesia, 1986.

Manan Sailan dan Irfana Lutia Ilyas. "Implementasi Pemenuhan Hak Mendapatkan Makanan Yang Layak Bagi Narapidana Di Lembaga Pemasyarakatan Klas 1 Makassar.” Jurnal Supremasi 13, no. 2 (2018): 95.

Santoso, Sani Imam. PENJARA SWASTA Sebuah Pendekatan Kriminologi dan Teori Keadilan Untuk Kepatutan di Indonesia. Jakarta: Sabero Inti Persada, 2019.

SDIT Al Hasanah. "Bagaimana Kriteria Makanan Halal Menurut Islam?” https:// sdit.alhasanah.sch.id/. Last modified 2020. https://sdit.alhasanah.sch.id/pengetahuanumum/bagaimana-kriteria-makanan-halalmenurut-islam/.

Tim Peneliti. Penelitian Hukum tentang Evaluasi Permenkum 40 Tahun 2017 tentang Evaluasi Atas Implementasi Permenkumham Nomor 40 Tahun 2017 tentang Pedoman Penyelenggaraan Makanan Bagi Tahanan Anak dan Narapidana di Rutan, LPKA, dan Lembaga Pemasyarakatan, 2021.

Yuliana Primawardani. "Perawatan Fisik Terkait Penyediaan Makanan Dan Minuman Bagi Narapidana Di Lembaga Pemasyarakatan Ditinjau Dari Pendekatan Hak Asasi Manusia.” Jurnal Ilmiah Kebijakan Hukum 11, no. 2 (2017): 165.

Yusuf, Syeikh Abdul Hayy. "Keluhuran Nilai Islam Memperlakukan Narapidana.” Republika.co.id. Last modified 2018. https://republika.co.id/berita/duniais la m/islamnus antara/18/02/05/ p3oh5a313-keluhuran-nila i-is la mmemperlakukannarapidana. 
HALAMAN KOSONG

446 | Jurnal Penelitian Hukum De Jure Vol. 21 No. 4, December 2021: 435-446 